Brit. f. industr. Med., 1966, 23, 188

\title{
Prevalence of Byssinosis and Dust Levels in Flax Preparers in Northern Ireland
}

\author{
P. C. ELWOOD, I. R. MCAULAY, $†$ R. H. MCLARIN, J. PEMBERTON, \\ G. C. R. CAREY and J. D. MERRETT \\ From the Department of Social and Preventive Medicine, Queen's University, Belfast
}

\begin{abstract}
The association between the prevalence of both byssinosis and chronic bronchitis and the level of airborne dust was examined in workers in preparing departments in flax mills in Northern Ireland. A weak association between the dust level and byssinosis was found but not between the dust level and chronic bronchitis. It is suggested that the disparity of these associations may have arisen because the diagnosis of byssinosis, as in most recent published studies, was based on relatively acute and reversible symptoms which are more likely to be closely related to the current dust levels than the slowly developing symptoms on which the diagnosis of chronic bronchitis was based. Furthermore an association between chronic bronchitis and the dust levels is likely to be obscured to some extent by the effects of other non-industrial respiratory irritants such as tobacco smoke. Some hypotheses of the basic aetiology of byssinosis are discussed.
\end{abstract}

An association between the concentration of airborne dust in the working environment and the prevalence of respiratory symptoms in textile workers has been found by various authors (Roach and Schilling, 1960; Mair, Smith, Wilson, and Lockhart, I960; Bouhuys, Van Duyn, and Van Lennep, 196I). Most writers have noted that it is workers in the early preparing textile processes who appear to be at the greatest risk of developing byssinosis, and it is these workers who are usually exposed to the highest levels of airborne dust. Within cotton carding rooms the proximity of workers to carding engines has been shown to be associated with the degree to which they suffer from ill health in general (Home Office, 1932) and byssinosis in particular (Schilling, Hughes, DingwallFordyce, and Gilson, 1955).

Roach and Schilling (1960) attempted to derive a quantitative relationship between the prevalence of byssinosis and the level of airborne dust in five selected Lancashire cotton mills. They correlated the prevalence of byssinosis in 309 workers in 10 groups defined by work-room, or type of room, with the mean level of airborne dust in these rooms at the times of the study. Batawi, Schilling, Valice, and

$\star$ Present address: Medical Research Council, Epidemiological Research Unit (South Wales), Cardiff.

+Present address: Department of Physics, Trinity College, Dublin.

Received for publication August 17, 1965.
Walford (1964) presented a similar type of analysis based on the dust levels and prevalence of byssinosis in four Egyptian cotton rooms. They showed that the mean change within a day in a lung function test (indirect maximum breathing capacity-I.M.B.C.) in the workers in each room was correlated with the dust concentrations in the rooms "both of which are also related to prevalence of byssinosis'. The correlation coefficient $(r)$ between the dust concentration in four rooms and the mean fall in I.M.B.C. of the workers in each room was 0.95 .

During a survey of the flax industry in Northern Ireland, a full report of which has been given elsewhere (Carey, Elwood, McAulay, Merrett, and Pemberton, 1965), data were collected relating to the prevalence of byssinosis and various respiratory symptoms (Elwood, Pemberton, Merrett, Carey, and McAulay, 1965), and the concentrations of airborne dust in rooms in the flax mills were measured (McAulay, Carey, Merrett, McLarin, Elwood, and Pemberton, 1965). An association between the type of occupation within the flax mill and the prevalence of byssinosis was found, there being significantly more cases than expected on a null hypothesis among the preparers and significantly fewer than expected among the non-preparers; a similar association was shown between occupation and chronic bronchitis. Although there were considerable variations in the dust levels of rooms in which any particular process was being carried out, pre- 
paring rooms were found to be, in general, considerably more dusty than the non-preparing rooms. There were therefore strong a priori reasons for believing that the prevalences of byssinosis and of chronic bronchitis were directly related to the degree of dustiness of the rooms.

This paper discusses the association between the prevalence of both byssinosis and chronic bronchitis in preparing workers in mills which handled flax alone or flax and synthetic fibres and the current level of airborne dust in the working environment. The analysis is confined to preparing workers as the prevalence of byssinosis in non-preparers was low, and although in certain non-preparing sub-groups, e.g., 'other finishers', an appreciable proportion of workers was affected, it was felt that a more reliable estimate of the true associations could be derived from preparers alone, as these appeared to constitute a population which was fairly homogeneous with regard to working conditions.

In this report the workers and the workrooms studied, the methods used, the definitions of the types of mill, byssinosis, chronic bronchitis, smoking habits, preparing and non-preparing processes, and the age grouping of workers are as described by Elwood and his colleagues (1965). The definitions of byssinosis and chronic bronchitis are given in an appendix to this paper (p. 193). Certain exclusions in addition to those described by McAulay et al. (1965) had to be made, because in some of the preparing rooms in which dust measurements were made all workers were below the age limit of the survey, i.e., under 35 years. Furthermore, some workers are omitted who are described by Elwood and his colleagues (1965) since they had worked in preparing rooms for which no data relating to dust levels had been obtained. The reasons for these latter omissions are given by McAulay and his colleagues (1965). It is not thought that they seriously impair the present study as they occurred, in most cases, for technical reasons (for example, absence of convenient electric power points in a workroom), and the workers so excluded are not known to differ in any important respect from those included. Neither is the omission of data relating to workers who were absent or who refused to co-operate likely to be of serious consequence in this context since these have been shown to be only about $3 \%$ of the total available population (Elwood et al., 1965).

\section{Methods of Analysis}

There were 35 preparing rooms in which flax was handled, and 22 in which flax and synthetic fibres were handled. In only eight and seven of these respectively did the total number of workers of either sex exceed ten. These numbers were considered to be too small to justify the use of individual rooms as sampling units, and rooms were therefore grouped at three levels according to the mean dust level, separately for total dust and for respirable dust (dust composed of particles with an equivalent diameter of less than 7 microns). The limits of these three groups were defined so that, as near as possible, equal numbers of workers were included in each group, and these are (in $\mathrm{mg}$. dust/100 $\mathrm{m}^{3}$ air) (a) 398 and over, (b) I48 to 397 , and (c) under 148 for total dust; and (a) I66 and over, (b) Ioo to 165 , and (c) under 100 for respirable dust. The observed numbers of preparers with each grade of byssinosis or, separately, chronic bronchitis, in rooms so grouped, were compared with those expected on a null hypothesis. The null hypothesis used is that the distribution of workers by byssinosis and bronchitis grade is not associated with the level of airborne dust to which they were exposed at the time of the survey. These comparisons were made independent of the effects of differences in the distributions of workers by the type of mill (flax alone or flax plus synthetic), age, and smoking habit. A process of standardization, similar to that described by Elwood et al. (1965), was used to allow for the independent effects of these related factors, and this was done for workers of each sex, grouped separately by mean total dust level and mean respirable dust level in the workrooms. The significance of the differences between these observed and expected distributions has been assessed by $\chi^{2}$. The validity of the use of a $\chi^{2}$ test in this situation has been discussed by Elwood et al. (1965).

\section{Results and Discussion}

Tables I and II show the distribution of male and female workers respectively, by byssinosis and chronic bronchitis grade, in three groups defined by the total dust level in their working environment. Tables III and IV show the same data in groups defined by respirable dust level. Each of these distributions has been compared with that expected on a null hypothesis after standardization for the independent effects of the type of mill, age, and smoking habit. It seems that none of the associations is marked, other than that between the respirable dust level and byssinosis grade in women, which is probably significant at $P<0.05$, as is that between the total dust level and byssinosis grade in men. If the distributions for men and women are summed, thereby standardizing for sex, the associations for byssinosis appear to be significant $\left(\chi^{2}=13.91\right.$; D.F. $=6 ; 0.05>P>0.02$ for total dust; and $\chi^{2}=$ I8.36; D.F. $=6$; 0.01 $>\mathrm{P}>0.001$ for respirable dust) but those for bronchitis are not $\left(\chi^{2}=\mathrm{I} \cdot 13\right.$; D.F. $=4$; $0.90>\mathrm{P}>0.80$ for total dust and $\chi^{2}=1 \cdot 13 ; D . F .=4 ; 0.90>P>0.80$ for respirable dust). Certainly the differences between the observed and expected numbers in these tables 
TABLE I

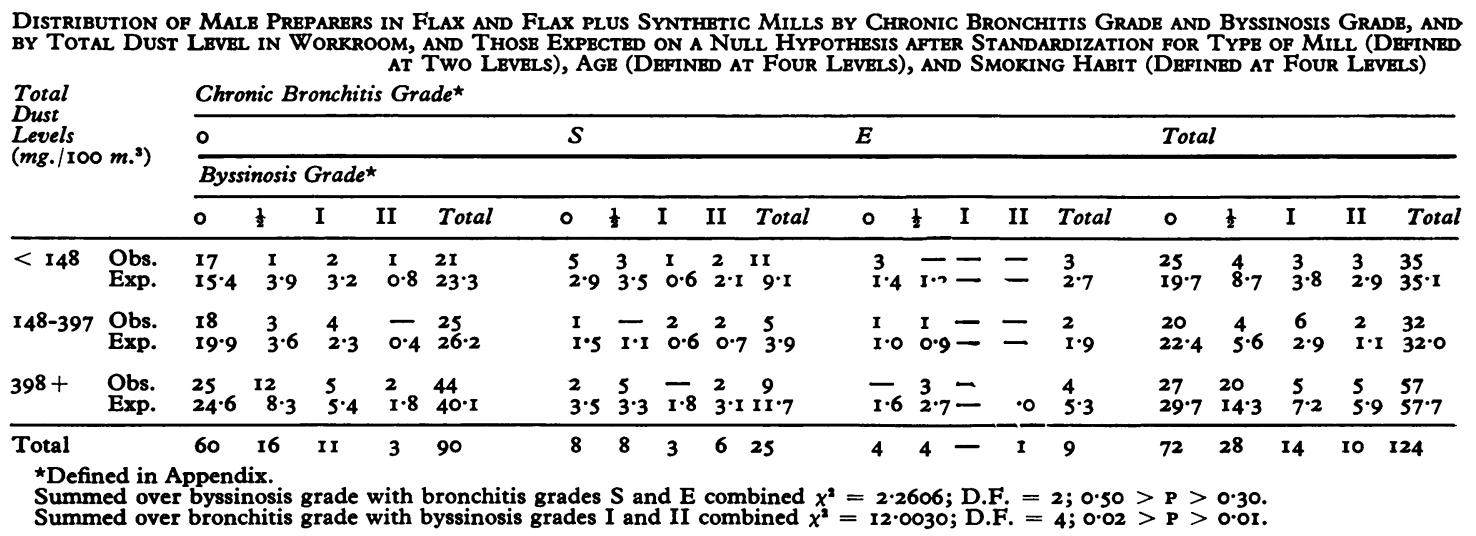

TABLE II

Distribution of Female Prgparers in Flax and Flax Plus Synthetic Mills by Chronic Bronchitis Grade, Byssinosis Grade, and

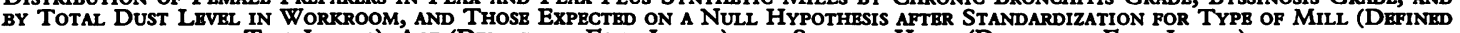

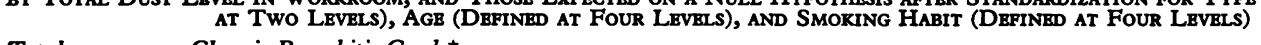

\begin{tabular}{|c|c|c|c|c|c|c|c|c|c|}
\hline \multirow{4}{*}{\multicolumn{2}{|c|}{$\begin{array}{l}\text { Total } \\
\text { Dust } \\
\text { Levels } \\
\text { (mg./100 m.3) }\end{array}$}} & \multicolumn{8}{|c|}{ Chronic Bronchitis Grade } \\
\hline & & 0 & & & & & $S$ & & \\
\hline & & \multicolumn{8}{|c|}{ Byssinosis Grade } \\
\hline & & 0 & $t$ & $I$ & II & Total & 0 & 南 I & $I I$ \\
\hline$<\mathbf{1 4 8}$ & $\begin{array}{l}\text { Obs. } \\
\text { Exp. }\end{array}$ & $\begin{array}{l}122 \\
112.6\end{array}$ & 6 & $\begin{array}{l}10 \\
14.3\end{array}$ & $\begin{array}{l}2 \\
2 \cdot 5\end{array}$ & $\begin{array}{l}149 \\
145.7\end{array}$ & $\begin{array}{l}9 \\
6.2\end{array}$ & $\begin{array}{ll}1 & 3 \\
1.6 & 3.9\end{array}$ & $\begin{array}{ll}1 & 14 \\
3.2 & 14.9\end{array}$ \\
\hline I48-397 & $\begin{array}{l}\text { Obs. } \\
\text { Exp. }\end{array}$ & $\begin{array}{l}110 \\
113.5\end{array}$ & $\begin{array}{l}18 \\
519 \cdot 1\end{array}$ & $\begin{array}{l}15 \\
11.4\end{array}$ & $\begin{array}{l}2 \\
2.5\end{array}$ & $\begin{array}{l}145 \\
146.5\end{array}$ & $\begin{array}{l}6 \\
6 \cdot 1\end{array}$ & $\begin{array}{ll}I \cdot 2 & 3 \\
I \cdot 2 & 2 \cdot 6\end{array}$ & $\begin{array}{ll}3 & 13 \\
2 \cdot 1 & 12 \cdot 0\end{array}$ \\
\hline $398+$ & $\begin{array}{l}\text { Obs. } \\
\text { Exp. }\end{array}$ & $\begin{array}{l}108 \\
113.9\end{array}$ & $\begin{array}{l}21 \\
918 \cdot 6\end{array}$ & $\begin{array}{l}12 \\
11 \cdot 2\end{array}$ & $\begin{array}{l}4 \\
3 \cdot 0 \\
\end{array}$ & $\begin{array}{l}145 \\
146.7\end{array}$ & $\begin{array}{l}4.7 \\
6.7\end{array}$ & $\begin{array}{ll}2 & 3 \\
1 \cdot 2 & 2.5 \\
\end{array}$ & $\begin{array}{cc}4 & 13 \\
2 \cdot 7 & 13 \cdot 1\end{array}$ \\
\hline \multicolumn{2}{|l|}{ Total } & 340 & 54 & 37 & 8 & 439 & 19 & 4 & 840 \\
\hline
\end{tabular}

are on the whole larger, and more consistent in direction, for byssinosis than for bronchitis.

The disparity of these associations is of considerable interest and suggests that the relationships between exposure to dust and byssinosis and chronic bronchitis differ in degree, though probably not in nature.

The symptoms on which a diagnosis of byssinosis is customarily based are relatively 'acute' and, except in the advanced stages, are probably reversible. Furthermore, these acute symptoms are probably causally related to the inhalation of certain textile dusts alone, and any quantitative change in the exposure of a subject to these dusts is likely to be followed closely by a change in the symptoms of that subject. A marked association between the prevalence of byssinosis in the present population and the current levels of flax dust to which they are exposed is therefore not surprising.
On the other hand, a diagnosis of chronic bronchitis is usually based on symptoms which are neither acute nor of recent origin and which are almost certainly causally related to the inhalation of a number of irritants, of which one may be certain textile dusts. Elwood et al. (1965), using occupation groups as a qualitative measure of the current dust level in these mills, found a significant and marked association between dust exposure and chronic bronchitis. However, although the symptoms of chronic bronchitis are probably reversible to some extent on the removal of a subject from, or the reduction of his exposure to, any single irritant, any improvement in symptoms which may occur is likely to be relatively small. The prevalence of the symptoms of chronic bronchitis in the present population would therefore not be expected to show as close an association with current flax dust levels in the workrooms as the symptoms of byssinosis, 
TABLE III

Distribution of Male Preparers in Flax and Flax Plus Synthetic Mills by Chronic Bronchitis Grade and Byssinosis Gradi AND BY RESPIRABLB DUST LEVEL IN WORKROOM AND THOSB EXPECTED ON A NULI HYPOTHESIS AFTBR STANDARDIZATION POR TYPE OF MILL

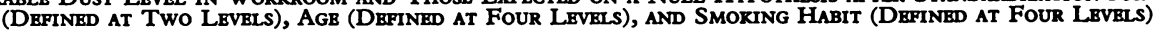

\begin{tabular}{|c|c|c|c|c|c|c|c|c|c|c|c|c|c|c|c|c|c|c|c|c|c|}
\hline \multirow{3}{*}{\multicolumn{2}{|c|}{$\begin{array}{l}\text { Respirable } \\
\text { Dust } \\
\text { Levels } \\
\left(\text { mg./100 m. } .^{2}\right)\end{array}$}} & \multicolumn{20}{|c|}{ Chronic Bronchitis Grade } \\
\hline & & 0 & & & & & $s$ & & & & & $\boldsymbol{E}$ & & & & & Tota & & & & \\
\hline & & \multicolumn{20}{|c|}{ Byssinosis Grade* } \\
\hline & & $\circ$ & $\frac{1}{2}$ & $I$ & $I I$ & Total & o & $\frac{1}{1}$ & $I$ & II & Total & 0 & $\frac{1}{2}$ & $I$ & II & Total & $\mathbf{0}$ & 1 & $\boldsymbol{I}$ & II & Total \\
\hline$<100$ & $\begin{array}{l}\text { Obs. } \\
\text { Exp. }\end{array}$ & $\begin{array}{l}22 \\
21 \cdot 8\end{array}$ & $\begin{array}{l}2 \\
5 \cdot 0\end{array}$ & $\begin{array}{l}4 \\
3 \cdot 7\end{array}$ & $\begin{array}{l}I \\
0.9\end{array}$ & $\begin{array}{l}29 \\
31 \cdot 4\end{array}$ & $\begin{array}{l}5 \\
3 \cdot 7\end{array}$ & $\begin{array}{l}3 \\
3 \cdot 7\end{array}$ & $\begin{array}{l}I \\
0.4\end{array}$ & $\begin{array}{l}3 \\
2 \cdot 3\end{array}$ & $\begin{array}{l}12 \\
10 \cdot 1\end{array}$ & $\begin{array}{l}4 \\
2 \cdot 1\end{array}$ & $\overline{1 \cdot 3}$ & 二 & $\overline{-}$ & $\begin{array}{l}4 \\
3 \cdot 4\end{array}$ & $\begin{array}{l}31 \\
27 \cdot 6\end{array}$ & ${ }_{10}^{5} \cdot 0$ & $\begin{array}{l}5 \\
4 \cdot 1\end{array}$ & $\begin{array}{l}4 \\
3 \cdot 2\end{array}$ & $\begin{array}{l}45 \\
44.9\end{array}$ \\
\hline $100-165$ & $\begin{array}{l}\text { Obs. } \\
\text { Exp. }\end{array}$ & $\begin{array}{l}31 \\
28 \cdot 5\end{array}$ & $\begin{array}{l}8 \\
7 \cdot 5\end{array}$ & $\begin{array}{l}3 \\
5 \cdot 0\end{array}$ & $\begin{array}{l}I \\
1 \cdot 7\end{array}$ & $\begin{array}{l}43 \\
42 \cdot 7\end{array}$ & $\begin{array}{l}3 \cdot 7 \\
2 \cdot 7\end{array}$ & $\begin{array}{l}2 \\
2 \cdot 5\end{array}$ & $\begin{array}{l}2 \\
1 \cdot 7\end{array}$ & $\begin{array}{l}2 \\
2 \cdot 3\end{array}$ & $\begin{array}{l}9 \\
9 \cdot 2\end{array}$ & $\overline{I \cdot I}$ & $\begin{array}{l}4 \\
3 \cdot 1\end{array}$ & $=$ & $\begin{array}{l}I \\
I \cdot 0\end{array}$ & $\begin{array}{l}5 \\
5 \cdot 2\end{array}$ & $\begin{array}{l}34 \\
32 \cdot 3\end{array}$ & $\begin{array}{l}14 \\
13 \cdot 1\end{array}$ & $\begin{array}{l}5 \\
6 \cdot 7\end{array}$ & $\begin{array}{l}4 \\
5 \cdot 0\end{array}$ & $\begin{array}{l}57 \\
57 \cdot 1\end{array}$ \\
\hline $166+$ & $\begin{array}{l}\text { Obs. } \\
\text { Exp. }\end{array}$ & $\begin{array}{l}7 \\
9 \cdot 5\end{array}$ & $\begin{array}{l}6 \\
3 \cdot 1\end{array}$ & $\begin{array}{l}4 \\
2 \cdot 3\end{array}$ & $\begin{array}{l}I \\
0 \cdot 4\end{array}$ & $\begin{array}{l}18 \\
15 \cdot 3\end{array}$ & $\overline{1.5}$ & $\begin{array}{l}3 \\
1.5\end{array}$ & $\overline{0.9}$ & $\begin{array}{l}\mathbf{I} \\
\mathbf{I} \cdot \mathbf{3}\end{array}$ & $\begin{array}{l}4 \\
5 \cdot 2\end{array}$ & $\overline{0.8}$ & $\overline{0.5}$ & 三 & $=$ & $\overline{x \cdot 3}$ & $\begin{array}{l}7 \\
11 \cdot 8\end{array}$ & $\begin{array}{l}9 \\
5 \cdot 1\end{array}$ & $\begin{array}{l}4 \\
3 \cdot 2\end{array}$ & $\begin{array}{l}2 \\
1 \cdot 7\end{array}$ & $\begin{array}{l}22 \\
21 \cdot 8\end{array}$ \\
\hline & & 60 & 16 & I I & 3 & 90 & 8 & 8 & 3 & 6 & 25 & 4 & 4 & - & I & 9 & 72 & 28 & 14 & 10 & 124 \\
\hline
\end{tabular}

$\star$ Defined in Appendix.

Summed over byssinosis grade with bronchitis grades $S$ and E combined $\chi^{2}=1.5449 ;$ D.F. $=2 ; 0.50>P>0.30$.

Summed over bronchitis grade with byssinosis grades I and II combined $\chi^{2}=9 \cdot 2705$; D.F. $=4$; 0.10 $>$ P $>0.05$.

TABLE IV

Distribution of Female Preparers in Flax and Flax Plus Synthetic Mills by Chronic Bronchitis Grade and Byssinosis Gradi (Drfined at Two Levels), Age (Drfined at Four LeVels), and Smoking Habit (Depined at Four LeVeis)

\begin{tabular}{|c|c|c|c|c|c|c|c|c|c|c|c|c|c|c|c|c|c|c|c|c|c|}
\hline \multirow{3}{*}{\multicolumn{2}{|c|}{$\begin{array}{l}\text { Respirable } \\
\text { Dust } \\
\text { Levels } \\
\left.\text { (mg./100 m. }{ }^{3}\right)\end{array}$}} & \multicolumn{20}{|c|}{ Chronic Bronchitis Grade } \\
\hline & & 0 & & & & & $S$ & & & & & $\boldsymbol{E}$ & & & & & Tota & & & & \\
\hline & & \multicolumn{20}{|c|}{ Byssinosis Grade } \\
\hline & & 0 & $\frac{1}{2}$ & $I$ & $I I$ & Total & o & $\frac{1}{2}$ & $I$ & II & Total & 0 & $\mathbf{1}$ & $I$ & II & Total & 0 & $\frac{1}{2}$ & $I$ & II & Total \\
\hline$<100$ & $\begin{array}{l}\text { Obs. } \\
\text { Exp. }\end{array}$ & $\begin{array}{l}140 \\
129.0\end{array}$ & $\begin{array}{l}18 \\
19 \cdot 9\end{array}$ & $\begin{array}{l}12 \\
15.9\end{array}$ & $\begin{array}{l}2 \\
2 \cdot 9\end{array}$ & $\begin{array}{l}172 \\
167 \cdot 7\end{array}$ & $\begin{array}{l}10 \\
7 \cdot 1\end{array}$ & $\begin{array}{l}\mathrm{I} \\
\mathrm{I} \cdot 8\end{array}$ & $\begin{array}{l}2 \\
4 \cdot 4\end{array}$ & $\begin{array}{l}3 \\
3 \cdot 7\end{array}$ & $\begin{array}{l}16 \\
17 \cdot 0\end{array}$ & $\begin{array}{l}2 \\
2 \cdot 6\end{array}$ & $\begin{array}{l}\text { I } \\
\text { I.O }\end{array}$ & $\begin{array}{l}1 \\
1.5\end{array}$ & $\begin{array}{l}2 \\
3 \cdot 9\end{array}$ & $\begin{array}{l}6 \\
9 \cdot 0\end{array}$ & $\begin{array}{l}152 \\
138 \cdot 7\end{array}$ & $\begin{array}{l}20 \\
22 \cdot 7\end{array}$ & $\begin{array}{l}15 \\
21.8\end{array}$ & $\begin{array}{l}7 \\
10.5\end{array}$ & $\begin{array}{l}194 \\
193.7\end{array}$ \\
\hline $100-165$ & $\begin{array}{l}\text { Obs. } \\
\text { Exp. }\end{array}$ & $\begin{array}{l}134 \\
137.0\end{array}$ & $\begin{array}{l}24 \\
23 \cdot 3\end{array}$ & $\begin{array}{l}17 \\
13.8\end{array}$ & $\begin{array}{l}2 \\
3 \cdot 3\end{array}$ & $\begin{array}{l}177 \\
177.4\end{array}$ & $\begin{array}{l}7.9 \\
7.9\end{array}$ & $\begin{array}{l}2 \\
1 \cdot 3\end{array}$ & $\begin{array}{l}4 \\
3 \cdot 1\end{array}$ & $\begin{array}{c}2 \\
2 \cdot 3\end{array}$ & $\begin{array}{l}15 \\
14.6\end{array}$ & $\begin{array}{l}5 \\
4 \cdot 1\end{array}$ & $\begin{array}{l}2 \\
1 \cdot 3\end{array}$ & $\begin{array}{l}2 \\
1 \cdot 4\end{array}$ & $\begin{array}{l}2 \\
3.8\end{array}$ & $\begin{array}{l}11 \\
10.6\end{array}$ & $\begin{array}{l}146 \\
149 \cdot 0\end{array}$ & $\begin{array}{l}28 \\
25 \cdot 9\end{array}$ & $\begin{array}{l}23 \\
18 \cdot 3\end{array}$ & $\begin{array}{l}6 \\
9 \cdot 4\end{array}$ & $\begin{array}{c}203 \\
202 \cdot 6\end{array}$ \\
\hline $166+$ & $\begin{array}{l}\text { Obs. } \\
\text { Exp. }\end{array}$ & $\begin{array}{l}66 \\
74 \cdot 0\end{array}$ & $\begin{array}{l}12 \\
10.7\end{array}$ & $\begin{array}{l}8 \\
7 \cdot 3\end{array}$ & $\begin{array}{l}3 \\
1 \cdot 8\end{array}$ & $\begin{array}{l}89 \\
93.8\end{array}$ & $\begin{array}{l}2 \\
4.0\end{array}$ & $\begin{array}{l}\text { I } \\
0.9\end{array}$ & $\begin{array}{l}3.5 \\
1.5\end{array}$ & $\frac{4}{2 \cdot 1}$ & $\begin{array}{l}10 \\
8.5\end{array}$ & $\begin{array}{l}2 \\
2 \cdot 0\end{array}$ & $\overline{0.7}$ & $\begin{array}{l}1 \\
0.8\end{array}$ & $\begin{array}{c}6 \\
2 \cdot 2\end{array}$ & $\begin{array}{l}9 \\
5 \cdot 7\end{array}$ & $\begin{array}{l}70 \\
80 \cdot 0\end{array}$ & $\begin{array}{l}13 \\
12 \cdot 3 \\
\end{array}$ & $\begin{array}{l}12 \\
9 \cdot 6 \\
\end{array}$ & $\begin{array}{l}13 \\
6 \cdot 1\end{array}$ & $\begin{array}{l}108 \\
108 \cdot 0\end{array}$ \\
\hline Total & & 340 & 54 & 37 & 7 & 438 & 19 & 4 & 9 & 9 & $4 \mathrm{I}$ & 9 & 3 & 4 & 10 & 26 & 368 & 6r & 50 & 26 & 505 \\
\hline
\end{tabular}

$\star$ Defined in Appendix.

Summed over byssinosis grade $x^{2}=3.6355 ;$ D.F. $=4$; $0.50>P>0.30$.

Summed over bronchitis grade $\chi^{2}=17.2462 ; D$. F. $=6$; $0.01>P>0.001$.

although if we had reliable estimates of the past dust exposure of each worker this position might well be reversed.

It seems likely therefore that the association between chronic bronchitis and current dust level in the present population may be obscured because of the chronic nature of the symptoms of chronic bronchitis, their multiple aetiology, and their relative irreversibility. It may also be that the limitation of the present study to workers exposed to a relatively restricted range of dust levels, i.e., workers in preparing departments, has mitigated against the detection of a significant relationship, particularly in view of the multiple aetiology of these symptoms, but it seemed advisable to confine this study to a group of workers which was relatively homogeneous with regard to working conditions in general.

It is also possible that the relationships between either chronic bronchitis and/or byssinosis and current dust levels may have been obscured to some extent by bias in these data. It is known that there were changes in the population exposed to flax dust in these mills due to the selective discharge of workers suffering from respiratory symptoms (Elwood, 1965), and considerable changes in the dust levels in the workrooms in these mills almost certainly occurred before the survey. While most of these changes probably led to a reduction in the airborne dust levels we have no data to substantiate this. Changes in both the population and their environment could well have obscured an association between chronic bronchitis, which is slowly developing, disabling, and probably only partially reversible, to a much greater degree than byssinosis, as the symptoms on which byssinosis is usually diagnosed are acute and largely reversible.

Another source of possible bias in this study is differences between sub-groups of workers in their durations of exposure to textile dust. Again bias from this source is much more likely to obscure a 


\section{P. C. Elwood, I. R. McAulay, R. H. McLarin, F. Pemberton, G. C. R. Carey and F. D. Merrett}

relationship between current dust levels and chronic bronchitis than one between current dust level and the acute symptoms of byssinosis. During our survey the duration of employment of each worker in preparing stages in the flax industry was obtained (hereafter referred to as 'duration of employment'). We have examined these data by analyses of variance, and found that within both sexes there was evidence of significant heterogeneity in the duration of employment of workers when grouped either by dust level, byssinosis, or grade of chronic bronchitis. However, the relationships between duration of employment and dust level, as well as those between duration of employment and both byssinosis and chronic bronchitis grade, are complex. Furthermore, within each sex differences between the mean durations of employment of sub-groups of workers when defined by both dust level and byssinosis, as well as when defined by both dust level and chronic bronchitis, are on the whole small and show no consistent trends. Therefore while the omission of all reference to the duration of employment may have introduced bias into the analyses of the data which we present here (Tables I to IV), we feel that this omission is unlikely to be important. Certainly neither the extent nor the direction nor even the relative importance of the bias for the two respiratory conditions considered here can be easily assessed, particularly in view of the changes in the population and their environment which took place before the survey.

At this stage it is probably worth while to consider the basic hypotheses underlying work in this field and the light thrown on them by work up to the present. Unfortunately, there seem to have been no epidemiological studies of chronic bronchitis in textile workers other than those of Lammers, Schilling, and Walford (1964) and Elwood et al. (1965), so what follows is largely confined to the association between byssinosis and the dust level.

The main hypothesis, which is discussed by Schilling and Roach (196I), is that the prevalence rate of byssinosis is related to the dose of textile dust retained, this latter being dependent both on the concentration of dust to which workers have been exposed and the total length of their exposure. Such an association can only be tested satisfactorily by deriving a 'dose-response' type of relationship, such as that which was shown to exist between exposure to coal dust and pneumoconiosis (Roach, 1953), but it is improbable that sufficient valid data will be available to do this in the textile industry for many years. Meanwhile one can only assess the compatibility of the other evidence with this hypothesis. The strongest evidence in its support seems to be that of Roach and Schilling (1960) and Schilling and Roach (196I), who found a positive relationship between the prevalence of byssinosis, duration of exposure, and concentration of dust. However, these workers did not examine the possible importance of smoking habit and have no firm data relating to dust concentration in the past, though they do state that as far as was known none of the mills had changed in any important respect during the 20 years immediately preceding their study. Our data too are deficient in details relating to the dust concentration in the past but they show a similar relationship to that found by these other workers. In the absence of more adequate data, in particular with respect to dust levels over a long period, only indirect support for the 'dose-response' hypothesis is likely to be available.

An alternative hypothesis is that the prevalence of byssinosis varies only with the concentration of textile dust to which a group is exposed at any particular time. In its extreme form this may be likened to the attack rate of sneezing in relation to the concentration of an irritant, such as pepper in the air. A great deal of the evidence relating to prevalence presented by Roach and Schilling (1960), Schilling and Roach (196I), and Batawi et al. (1964) could be explained on such a basis, and a hypothesis of this nature does seem to be particularly suitable to explain the relatively acute changes in I.M.B.C. reported by Batawi et al. (1964).

In general, it seems that a combination of these two hypotheses can best explain the association between byssinosis and the inhalation of textile dusts. The part played by variations in individual susceptibility in determining the epidemiological pattern of byssinosis may be important but is unknown. Elsewhere we have suggested that byssinosis can best be considered as a group of acute symptoms superimposed on a basic chronic bronchitic process (Elwood et al., I965). It seems likely that the acute and largely reversible symptoms are closely related to the dust concentration prevalent at any one time, and it is these symptoms on which most authors base the diagnosis of byssinosis. However, the chronic symptoms of bronchitis, in the production of which irritants other than textile dusts, such as tobacco smoke and air pollution, may be implicated, are much less likely to show a close relationship to the current dust level, and this relationship, if present, seems likely to be of a 'doseresponse' nature.

The finding of a basic association between chronic bronchitis and occupation group within flax mills by Elwood et al. (1965), and the absence of a marked association between these symptoms and the current dust level when the analysis is confined to the groups most heavily exposed to dust, seems to con- 
nirm the importance of reducing, substantially and permanently, the exposure of workers to respiratory irritants of all kinds, including flax dust.

\section{Appendix}

Symptoms of chronic bronchitis were graded for this study as follows:-

Grade o: No chronic bronchitis. No evidence of the production of phlegm from the chest of sufficient severity to be graded below.

Grade S: Simple chronic bronchitis. Evidence of the production of phlegm from the chest first thing in the morning and/or during the day and/or night on most days for a period of at least three months each year, for at least the past two years, without a recent exacerbation as described below.

Grade E: Chronic bronchitis with an exacerbation. Evidence of the presence of simple chronic bronchitis as defined above but including a period of increased production of phlegm lasting three weeks; and/or a chest illness with an increased production of phlegm causing an absence from work for at least one week within the last three years.

Symptoms of byssinosis were graded as follows:-

Grade $0:$ No evidence of breathlessness or chest tightness or discomfort of the chest on Mondays, nor of cough or wheezing which is worse on Mondays than on other days.

Grade $\frac{1}{2}$ : Evidence of breathlessness and/or chest tightness and/or discomfort of the chest on some Mondays, and/or cough or wheezing which is always worse on Mondays than on other days.

Grade I: Evidence of breathlessness and/or chest tightness on every Monday but not on other days.

Grade II: Evidence of breathlessness and/or chest tightness and/or discomfort of the chest on every Monday and also on some other days, provided that at one time in the past symptoms were confined to Monday.

'Monday' is used to imply the working hours, or the period immediately following, i.e., the period spent travelling home from work, during the first day of each week.

This investigation was supported in part by a grant from the Northern Ireland Ministry of Labour and National Insurance. We wish to thank the Northern Ireland Flax Spinners' Association Limited, the textile branch of the Amalgamated and General Workers Trade Union, and the managers, staff, and employees of the mills surveyed for the great help and co-operation which we received from them.

We wish to thank Professor E. A. Cheeseman for statistical advice and Miss J. Broderick, Miss B. Jackson, Mrs. J. J. McCabe, Mrs. L. A. McCreight, and Miss T. Pitt for help in preparing this paper.

\section{REFERENCES}

Batawi, M. A. El., Schilling, R. S. F., Valić, F., and Walford, J. (1964). Brit. F. industr. Med., 21, 13.

Bouhuys, A., Van Duyn, J., and Van Lennep, H. J. (I96I). Arch. environm. Hlth, 3, 499.

Carey, G. C. R., Elwood, P. C., McAulay, I. R., Merrett, J. D., and Pemberton, J. (1965). Byssinosis in flax workers in Northern Ireland. A report to the Minister of Labour and National Insurance, the Government of Northern Ireland. Belfast, H.M.S.O.

Elwood, P. C., Pemberton, J., Merrett, J. D., Carey, G. C. R., and McAulay, I. R. (1965). Brit. F. industr. Med., 22, 27.

(1965). Ibid., 22, 38 .

Home Office (1932). Report of the departmental committee on dust in card rooms in the cotton industry. London, H.M.S.O.

Lammers, B., Schilling, R. S. F., and Walford, J. (I964). Brit. $\mathcal{F}$. industr. Med., 21 , 124.

McAulay, I. R., Carey, G. C. R., Merrett, J. D., McLarin, R., Elwood, P. C., and Pemberton, J. (I965). Ibid., 22, 305.

Mair, A., Smith, D. H., Wilson, W. A., and Lockhart, W. (I960). Ibid., 17, 272.

Roach, S. A. (1953). Ibid., 10, 220.

and Schilling, R. S. F. (1960). Ibid., 17, I.

Schilling, R. S. F., and Roach, S. A. (196I). Pure and Applied Chemistry, 3, 69.

- Hughes, J. P. W., Dingwall-Fordyce, I., and Gilson, J. C. (1955). Brit. F. industr. Med., 12, 217. 